\title{
ANTI PROLIFERATIVE ACTIVITY OF CALAMUS ROTANG AS A SPOTLIGHT ON EHRLICH'S ASCITES CARCINOMA TREATED PERITONEAL AS WELL AS SOLID TUMOR MODEL
}

\author{
SUBEER ROY, DIKSHA KUMARI, MAINAK CHAKRABORTY, PALLAB KANTI HALDAR* \\ Department of Pharmaceutical Technology, Jadavpur University, Kolkata 700032, West Bengal, India \\ Email: pallab_haldar@rediffmail.com
}

Received: 19 Jul 2017 Revised and Accepted: 22 Nov 2017

\section{ABSTRACT}

Objective: Methanol extract of Calamus rotang (MECR) root was appraised as a spotlight for the candidate of anticancer activity through the vehicle (Ehrlich Ascites Carcinoma) on Swiss albino mice.

Methods: In vitro cytotoxicity assay has been accessed by trypan blue and MTT assay. In vivo anticancer activity was done using EAC cells $\left(2 \times 10^{6}\right)$ where in each groups mice were 6 . After treatment with MECR at the lower dose of 200 and higher dose of $400 \mathrm{mg} / \mathrm{kg}$ respectively for $9 \mathrm{~d}$, half of the mice of each group were sacrificed and the rest were kept to check prolongation of life span. The anticancer potential of MECR was evaluated by tumor volume, viable and nonviable tumor cell count, tumor weight, hematological parameters, biochemical estimations and Furthermore, tissue antioxidant parameters. Besides, solid tumor activity was also inspected.

Results: In MECR treated groups (200 and $400 \mathrm{mg} / \mathrm{kg}$ ) tumor volume, packed cell volume and viable cell count was significantly lessened as compared to that of the EAC control group. Life span, most reliable criteria for anticancer study, increased quite surprisingly by $50 \%$ and $100 \%$ in a dose dependant manner while compared to EAC control group. The hematological, biochemical and liver tissue antioxidant parameter are significantly $(\mathrm{p}<0.05)$ restored along with solid tumor case study (solid tumor volume) towards the normal level after treatment with MECR.

Conclusion: From the above study it can be inferred that the MECR has impressive anticancer activity in dose dependent way.

Keywords: MECR, MTT, EAC, Antioxidant, Anticancer, Solid tumor

(C) 2018 The Authors. Published by Innovare Academic Sciences Pvt Ltd. This is an open access article under the CC BY license (http://creativecommons.org/licenses/by/4.0/) DOI: http://dx.doi.org/10.22159/ijpps.2018v10i1.21449

\section{INTRODUCTION}

Cancer, one of the most serious issues in the world, has now focused its precedence in terms of mortality worldwide after cardiovascular disease. A core research with new approaches has been under running to deal with this vital phenomenon. Cancer is a group of diseases possessing many hallmark characteristics of cancer cell with manifestation of cancer catalog among which six essential alterations in cell physiology that collectively depict malignant growth comprising of self-sufficiency in growth signals, insensitivity to growth-inhibitory signals, evasion of programmed cell death (apoptosis), limitless replicative potential, sustained angiogenesis as well as tissue invasion with metastasis excessively meet the criteria to suit with cancer[1]. One of the requisite of cancer chemo preventive agent presently used is alleviation of damaged or malignant cells through cell cycle inhibition or induction of apoptosis without affecting normal cells [2]. Due to abundance of plants that synthesize bioactive compounds possessing antitumor properties and also cost effectiveness, plants have become a new searchlight for grabbing the opportunity to fight against excrescence and are expected to enhance higher excellence of life. As such, medicinal plants have been consumed as medication for cancer [3]. Approximately $60 \%$ of drugs currently used for cancer treatment have been isolated from natural products [4].

Calamus rotang (Family-Arecaceae), a shrub, is found in mainly coastal swamp forest which is indigenous to Southwest Asia like India, Bangladesh, Sri Lanka. It is a dioecious rattan palm that grows up to $10 \mathrm{~m}$ tall (basal section vertically) and $200 \mathrm{~m}$ wide (horizontally) and commonly known as 'bet' in Hindi, 'vetra' in Sanskrit and 'Rattan' in English. Cane is used for rough baskets, walking sticks, bags, chairs as furniture. Traditionally rattan is used as vermifuge in tribal people in Assam [5]. Fresh root juice is used in asthma, insomnia and chronic fever [6]. For many years it has assisted in treatment of various ailments like cough, leprosy and bleeding disorders whereas leaf sap of this medicinal plant is generally used for eye problem [7]. Rattan is also applied as antidiabetic, antidiarrhoeal and anti-inflammatory. Presence of flavonoids in the root of rattan is used in convulsions and cramps [8]. Exploration on phytochemical study implies the existence of alkaloids and flavonoids which carry potent antimutagenic and antimalignant traits are prime reason to establish this inspection. In this present study cytotoxic effect of methanol extract of Calamus rotang was evaluated against Ehrlich's Ascites Carcinoma (EAC) in Swiss albino mice.

\section{MATERIALS AND METHODS}

\section{Plant material}

Root of Calamus rotang ( $2 \mathrm{~kg}$ ) was collected near the coastal area of Sundarbans, West Bengal, of India in month of August 2016 and identified by the Botanical Survey of India, Botanic garden, Howrah, West Bengal, India. A voucher specimen (JU/SR-01) has been preserved at our laboratory for future scope. Roots were cleaned and dried for $4 \mathrm{~d}$ at $35-40{ }^{\circ} \mathrm{C}$ on roof ( $\mathrm{d}$ time $8 \mathrm{~h}$ ) and then shade dried for $2 \mathrm{~d}$ and pulverized in a mechanical grinder. Coarse powder (200 gm) was carried out in soxhlet apparatus by using methanol (14.5\% w/w, yield). The solvent was completely removed under reduced pressure at $40{ }^{\circ} \mathrm{C}$ in a rotary evaporator (Buchi R-210) and stored in vacuum desiccators for further use.

\section{Chemicals}

Sodium chloride, Propylene glycol, Trypan blue, Methyl violet, Sodium sulphate, Methylene blue, 5-Fluorouracil, MTT (MERCK Limited, Mumbai, India). All other chemicals and reagents used were of highest analytical grade.

\section{Animals}

Healthy male Swiss albino mice (weighing 20-22g) were taken to conduct the experiment. They were picked up from Chakraborty Enterprise, Kolkata, India. The mice were grouped and housed in poly acrylic cages $(38 \times 23 \times 10 \mathrm{~cm})$ maintaining not more than 6 animals per cage and preserved under standard laboratory 
conditions (temperature $25 \pm 2{ }^{\circ} \mathrm{C}$ and dark/light cycle $14 / 10 \mathrm{~h}$ ). They were permitted free access to standard dry pellet diet supplied by (Hindustan Lever, Kolkata, India) in India and water ad libitum. The mice were acclimatized to laboratory environment for $7 \mathrm{~d}$ before inception of the experiment.

\section{Acute toxicity}

OECD guideline 425 was followed for acute oral toxicity of methanol extract of Calamus rotang (root). The acute toxicity studies disclosed $\mathrm{LD}_{50}$ value up to $2000 \mathrm{mg} / \mathrm{kg}$ did not show any toxic effect.

One-fifth and one-tenth of the maximum safe dose of the extract used for acute toxicity were chosen for the in vivo experiment. Hence, the experimental dose was fixed as $200 \mathrm{mg} / \mathrm{kg}$ and 400 $\mathrm{mg} / \mathrm{kg}$ respectively for lower and higher dose.

\section{In vitro cytotoxicity assay}

In vitro cytotoxicity studies of MECR were performed by standard trypan blue $(0.4 \%)$ exclusion method and MTT assay [9]. The experiment was performed in triplicate.

\section{Transplantation of tumor}

Chittaranjan National Cancer Institute (CNCI), Kolkata, India was the source of EAC cells. EAC cells were maintained in vivo in Swiss albino mice by intraperitoneal transplantation of $2 \times 10^{6}$ cells per mouse after every $10 \mathrm{~d}$. Ascitic fluid was drawn out from EAC tumor bearing mouse at the log phase (d 7-8 of tumor bearing). Each animal received $0.1 \mathrm{ml}$ of tumor cell suspension containing $2 \times 10^{6}$ tumor cells intraperitoneally [10].

\section{Experimental protocol}

30 Swiss albino mice were divided into five groups $(n=6)$. All the animals in every groups except Group-I received EAC cells $\left(2 \times 10^{6}\right.$ cells/mouse i. p.). This was taken as d "0". Group-I worked as normal saline control ( $5 \mathrm{ml} / \mathrm{kg}$ i. p.) and group-II served as EAC control. $24 \mathrm{~h}$ after EAC transplantation, Group-III and IV received methanol extract of Calamus rotang (MECR) at a dose of 200 and $400 \mathrm{mg} / \mathrm{kg}$ i. p. for nine consecutive d, respectively. Group-V experienced 5 -FU $(20 \mathrm{mg} / \mathrm{kg}$ i. p.) as a reference drug for nine consecutive $d[10]$.

Twenty four hours from the last dose and $18 \mathrm{hr}$ of fasting, 3 animals of each group were sacrificed through cervical dislocation to find out antitumor, hematological and biochemical parameters and rest of the animals were placed with food and water ad libitum to monitor percentage increase in life span. The below parameters were examined from the sacrificed animals.

\section{Tumor parameters}

The ascitic fluid was withdrawn from the peritoneal cavity of the animals and the volume was measured by taking this fluid in a graduated tube (expressed in $\mathrm{ml}$ ). The packed cell volume was estimated by centrifuging the ascitic fluid at $3000 \mathrm{rpm}$ and noting the volume of the precipitate in $\mathrm{ml}$.

\section{Mean survival time}

The mean survival time ${ }^{*}=($ first death+Last death $) / 2$

*time denoted in $\mathrm{d}$

\section{Percentage increase in life span}

The effect of MECR on percentage increases in life span was calculated on the basis of mortality of the experimental mice [11].

ILS $(\%)=[($ Mean survival time of the treated group/Mean survival time of the control group)-1] $\times 100$

\section{Tumor cell count}

The ascitic fluid was taken in a WBC pipette and diluted 100 times with WBC fluid. Then a drop of the diluted cell suspension was placed on the Neubauer's counting chamber and the numbers of cells in the $64(4 \times 16)$ small squares were counted.

\section{Viable/nonviable tumor cell count}

The viability and non viability of the cell was observed by trypan blue assay. The cells were stained with trypan blue $(0.4 \%$ in normal saline) dye. The cells that didn't accept the dye were viable and those that took the dye were nonviable. These viable and nonviable cells were counted.

Cell count $=$ Number of cells $\times$ dilution factor $/$ Area $\times$ thickness of liquid film.

\section{Hematological parameters}

Blood was obtained from cardiac puncture that was used for total count of RBC, WBC and hemoglobin by standard method.

\section{Biochemical parameters}

Collected blood was set aside for 15 min to allow it to clot and then centrifuged at $5000 \mathrm{rpm}$ for $10 \mathrm{~min}$. The supernatants (serum) were collected and total protein, SGOT, SGPT and SALP were determined using the diagnostic reagent kit (Span Diagnostics Ltd, Surat, India).

\section{In vivo tissue antioxidant}

Livers and kidneys collected from the sacrificed animals were homogenized separately in $10 \mathrm{ml}$ of phosphate buffer $(20 \mathrm{mmol}$, $\mathrm{pH}-$ 7.4) and centrifuged at $12000 \mathrm{rpm}$ for $30 \mathrm{~min}$ at $4^{\circ} \mathrm{C}$. Inspection was carried out by measuring the level of lipid peroxidation [12] superoxide dismutase (SOD) [13]and nonenzymatic antioxidant system (reduced glutathione; GSH) [14].

\section{Solid tumor study}

Mice were divided into three groups $(n=6)$. Tumor cells $\left(1 \times 10^{6}\right.$ cells/mouse) were injected into the right hind limb (thigh) of all the animals intramuscularly. The mice of group I served as control. Group II received MECR $(400 \mathrm{mg} / \mathrm{Kg} / \mathrm{d}$, p. o.) and group III received $5-\mathrm{FU}(20 \mathrm{mg} / \mathrm{kg}$, i. p.). Tumor mass was measured from the $11 \mathrm{th} \mathrm{d}$ of tumor induction. The measurement was carried out every $5 \mathrm{~d}$ for a period of $30 \mathrm{~d}$. Tumor was measured using a vernier caliper at fixed intervals. The volume of tumor mass was calculated using the formula $V=4 / 3 \pi r^{2}$, where ' $r$ ' is the mean of ' $r 1$ ' and ' $r 2$ ' which are the two independent radii of the tumor mass [15]. On $31 \mathrm{~d}$ tumor mass was removed and weighed. $\%$ of Inhibition $=[$ (Tumor volume of Control on 30th D-Tumor Volume of Treated on $\left.30^{\text {th }} d\right) /($ Tumor volume of Control on $30^{\text {th }}$ D) $] \times 100$

\section{Statistic analysis}

All the data are given as mean \pm SEM of values obtained from three individual experiments. Data of all the experiments were analysed using analysis of variance (ANOVA) and group means were compared by Dunnett's by GraphPad Prism software version 5.1.

\section{RESULTS}

Fig. 1: (Trypan blue exclusion assay) and fig. 2 (MTT assay) are showing the results of in vitro cytotoxicity study on EAC cell line in a dose dependent way with IC 50 value of $195 \pm 5.41 \mu \mathrm{g} / \mathrm{ml}$ for Trypan blue exclusion assay and $114 \pm 7.82$ and $88.3 \pm 7.33 \mu \mathrm{g} / \mathrm{ml}$ for MTT assay ( 24 and $48 \mathrm{~h}$ respectively).

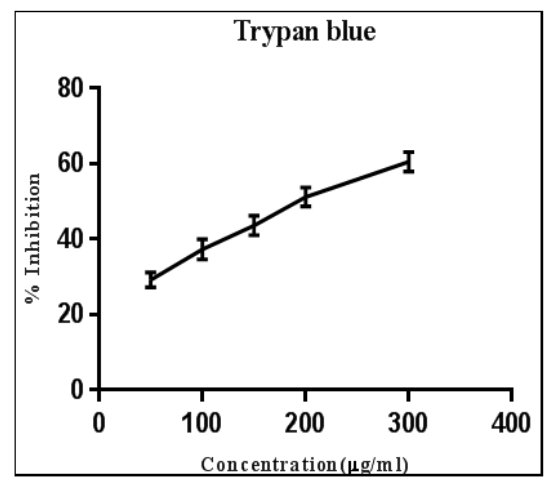

Fig. 1: Cytotoxic effect of MECR on in vitro EAC cell line by trypan blue, values are mean \pm SEM; where $n=6$ 


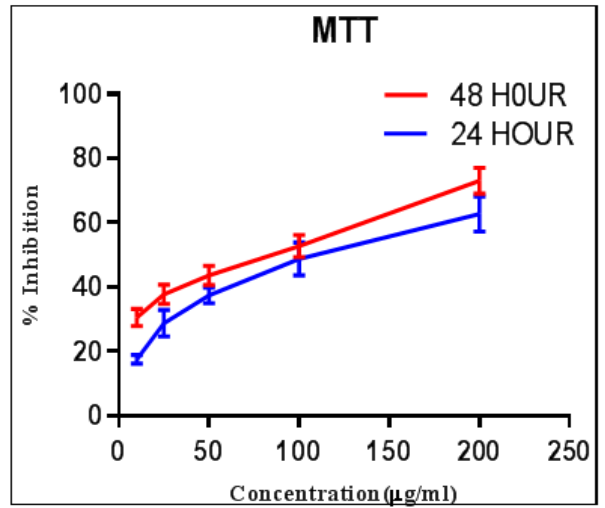

Fig. 2: Cytotoxic effect of MECR on in vitro EAC cell line by MTT assay, values are mean \pm SEM; where $n=6$
Administration of MECR (200 and $400 \mathrm{mg} / \mathrm{kg}$ ) intraperotoneally to EAC induced group significantly minimized the tumor volume, packed cell volume and the number of viable cells compared to the EAC control group while increasing the non-viable cells, mean survival time and percentage of life span (\%ILS) (table 1).

Table 2 depicts the picture of hematological changes in EAC treated groups. Leucocytes count was found to be reduced in treated group as compared to the EAC control group while RBC and hemoglobin levels were significantly elevated and restored towards normal levels. Table 3 indicates the alteration of serum biochemical enzyme estimation.

Liver specific functional markers like value of SGPT, SGOT and SALP of MECR treated groups (200 and $400 \mathrm{mg} / \mathrm{kg}$ ) along with reference drug restored to normal ones when compared to EAC control group. Total protein content escalated significantly $(\mathrm{p}<0.05)$ in the MECR treated groups and standard while comparing with EAC control group.

Table 1: Effect of MECR on tumor volume, packed cell volume, \% of viable and non viable cells, mean survival time and increase in life span

\begin{tabular}{|c|c|c|c|c|c|c|c|c|}
\hline \multirow[t]{2}{*}{ Groups } & \multirow{2}{*}{$\begin{array}{l}\text { Tumor volume } \\
(\mathrm{ml})\end{array}$} & \multirow{2}{*}{$\begin{array}{l}\text { Packed cell volume } \\
\text { (ml) }\end{array}$} & \multicolumn{2}{|c|}{ Cell count $\left(\times 10^{7} / \mathrm{ml}\right)$} & \multirow{2}{*}{$\begin{array}{l}\text { Viable } \\
\%\end{array}$} & \multirow[t]{2}{*}{ Non-viable\% } & \multirow{2}{*}{$\begin{array}{l}\text { MST } \\
\text { (D) }\end{array}$} & \multirow[t]{2}{*}{ ILS\% } \\
\hline & & & Viable & Non-viable & & & & \\
\hline $\begin{array}{l}\text { EAC } \\
\text { control }\end{array}$ & $2.10 \pm 0.06$ & $1.88 \pm 0.06$ & $7.74 \pm 0.27$ & $0.42 \pm 0.01$ & 94.77 & 5.22 & 18 & 00 \\
\hline $\mathrm{EAC}+200 \mathrm{mg} / \mathrm{kg}$ MECR & $1.30 \pm 0.05^{*}$ & $0.96 \pm 0.04^{*}$ & $5.72 \pm 0.11^{*}$ & $3.33 \pm 0.04^{*}$ & 63.15 & 36.84 & 27 & 50 \\
\hline $\mathrm{EAC}+400 \mathrm{mg} / \mathrm{kg}$ MECR & $0.83 \pm 0.08^{*}$ & $0.64 \pm 0.04^{*}$ & $4.00 \pm 0.05^{*}$ & $4.20 \pm 0.01^{*}$ & 48.82 & 51.17 & 36 & 100 \\
\hline $\mathrm{EAC}+5-\mathrm{FU}(20 \mathrm{mg} / \mathrm{kg})$ & $0.65 \pm 0.02^{*}$ & $0.37 \pm 0.02^{*}$ & $2.69 \pm 0.05^{*}$ & $5.45 \pm 0.05^{*}$ & 33.04 & 66.95 & 40 & 122.22 \\
\hline
\end{tabular}

Values are represented as mean \pm SEM. ${ }^{*} \mathrm{p}<0.05$ when EAC control compared with treated groups.

Table 2: Effect of MECR on hematological parameters

\begin{tabular}{|c|c|c|c|c|c|}
\hline Parameters & Normal & EAC control & $200 \mathrm{mg} / \mathrm{kg}$ MECR & $400 \mathrm{mg} / \mathrm{kg}$ MECR & $\begin{array}{l}20 \mathrm{mg} / \mathrm{kg} \\
5-\mathrm{FU}\end{array}$ \\
\hline 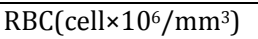 & $5.54 \pm 0.12$ & $2.69 \pm 0.05^{a}$ & $3.21 \pm 0.06^{b}$ & $4.75 \pm 0.02^{b}$ & $5.23 \pm 0.04^{\mathrm{b}}$ \\
\hline WBC $\left(\right.$ cell $\left.\times 10^{6} / \mathrm{mm}^{3}\right)$ & $4.56 \pm 0.02$ & $7.82 \pm 0.03^{\mathrm{a}}$ & $6.35 \pm 0.04^{b}$ & $5.22 \pm 0.08^{b}$ & $5.16 \pm 0.03^{b}$ \\
\hline $\mathrm{Hb}(\mathrm{g} / \mathrm{dl})$ & $11.32 \pm 0.06$ & $4.41 \pm 0.10^{\mathrm{a}}$ & $7.42 \pm 0.10^{\mathrm{b}}$ & $9.35 \pm 0.07^{b}$ & $10.90 \pm 0.04^{\mathrm{b}}$ \\
\hline
\end{tabular}

Values are represented as mean \pm SEM. ${ }^{\mathrm{a}} \mathrm{p}<0.05$ when compared to Normal, ${ }^{\mathrm{b}} \mathrm{p}<0.05$ when compared with EAC control group.

Table 3: Effect of MECR on serum parameter

\begin{tabular}{|c|c|c|c|c|c|}
\hline Parameters & Normal & EAC control & $200 \mathrm{mg} / \mathrm{kg}$ MECR & $400 \mathrm{mg} / \mathrm{kg}$ MECR & $\begin{array}{l}20 \mathrm{mg} / \mathrm{kg} \\
5-\mathrm{FU}\end{array}$ \\
\hline $\mathrm{TP}(\mathrm{g} / \mathrm{dl})$ & $8.85 \pm 0.25$ & $4.76 \pm 0.60^{\#}$ & $6.15 \pm 0.14^{*}$ & $7.19 \pm 0.14^{*}$ & $8.16 \pm 0.19^{*}$ \\
\hline SGOT(IU/l) & $86.00 \pm 2.08$ & $152.3 \pm 4.66^{\#}$ & $131.3 \pm 4.43^{*}$ & $87.57 \pm 4.45^{*}$ & $91.33 \pm 2.96^{*}$ \\
\hline SGPT(IU/l) & $37.00 \pm 3.46$ & $101.7 \pm 4.41^{\#}$ & $64.33 \pm 4.66^{*}$ & $46.67 \pm 4.41^{*}$ & $35.67 \pm 2.96^{*}$ \\
\hline SALP(KA/U) & $65.33 \pm 2.60$ & $131.3 \pm 3.52^{\#}$ & $117.3 \pm 3.84$ & $77.33 \pm 4.25^{*}$ & $70.33 \pm 3.18^{*}$ \\
\hline
\end{tabular}

Values are represented as mean \pm SEM. ${ }^{p} p<0.05$ when compared to Normal, ${ }^{*} \mathrm{p}<0.05$ when compared with EAC control group.

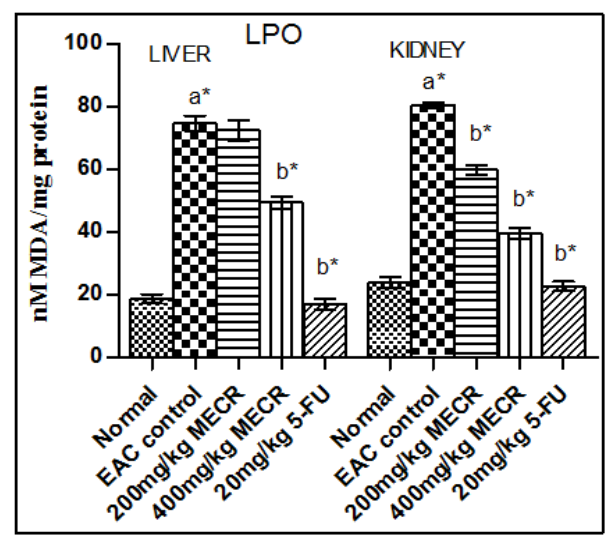

Fig. 3(a): Effects of different concentrations of MECR on lipid peroxidation. Values are represented as mean \pm SEM. a $^{*}$ p $<0.05$ EAC control compared to normal liver and kidney, ${ }^{b *} \mathbf{p}<0.05$ when treated groups compared to EAC liver and EAC kidney 
Antioxidant status of EAC bearing mice is described in fig. 3(a, b, c). The level of lipid peroxide (expressed as nM MDA/mg protein) was significantly increased in EAC control mice when compared to normal animals. The level of malondialdehyde decreased in the extract treated groups compared to the EAC control group thereby indicating the decrease in lipid peroxidation in the MECR treated groups. SOD activity was found to be declined in EAC control group as compared to normal. SOD activity enhanced in MECR (200 and $400 \mathrm{mg} / \mathrm{kg}$ ) treated groups as well as 5-FU while comparing to EAC control group. Same as in reduced glutathione level found in diminished in EAC control group that was notably reinstated to the near normal values by treatment with MECR in a dose dependent way.

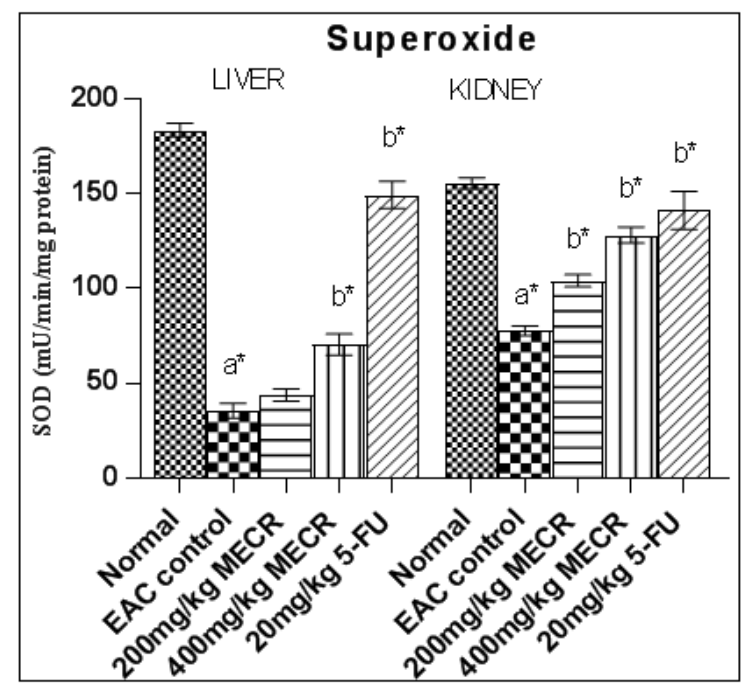

Fig. 3(b): Effects of different concentrations of MECR on SOD, values are represented as mean \pm SEM, ${ }^{a^{*}} \mathbf{p}<0.05$ EAC control compared to normal liver and kidney, ${ }^{\text {* }} \mathbf{p}<0.05$ when treated groups compared to EAC liver and EAC kidney

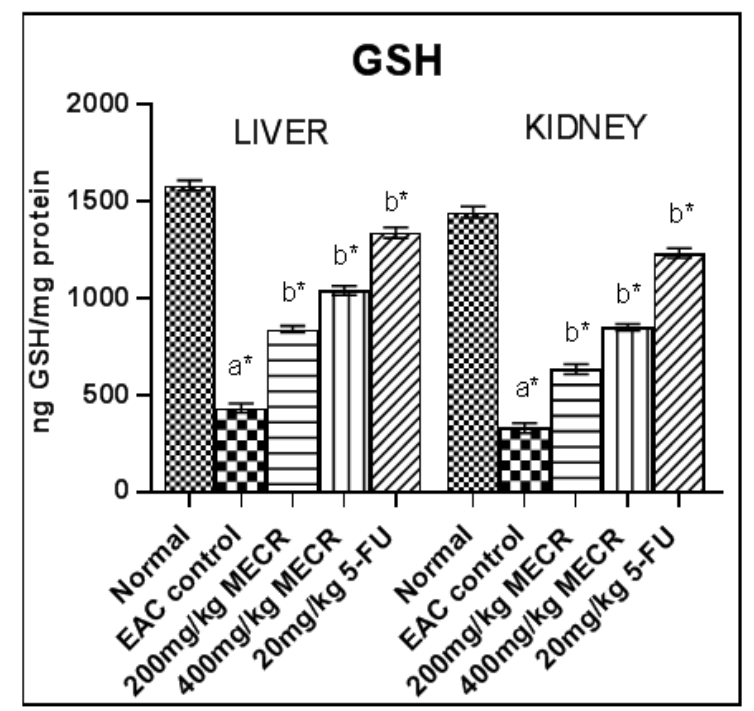

Fig. 3(c): Effects of different concentrations of MECR on GSH, values are represented as mean \pm SEM. ${ }^{a^{*}} \mathbf{p}<0.05$ EAC control compared to normal liver and kidney, ${ }^{b *} p<0.05$ when treated groups compared to EAC liver and EAC kidney

In solid tumor examination, tumor volume was lessened remarkably when treatment $(400 \mathrm{mg} / \mathrm{kg}$ ) was going on in contrast with EAC control group (table 4). Time related change in tumor volume was illustrated in fig. 4. A photographic portrayal of tumor size is figured out in fig. 5 .

Table 4: Effect of MECR on solid tumor volume

\begin{tabular}{|c|c|c|c|c|c|}
\hline \multirow[t]{2}{*}{ Groups } & \multicolumn{5}{|c|}{ Solid tumor volume(ml) } \\
\hline & D10 & D15 & D20 & D25 & D30 \\
\hline EAC Control & $2.88 \pm 0.13$ & $3.90 \pm 0.08$ & $4.55 \pm 0.19$ & $5.21 \pm 0.13$ & $6.44 \pm 0.22$ \\
\hline $400 \mathrm{mg} / \mathrm{kg}$ MECR & $2.57 \pm 0.07^{*}$ & $3.72 \pm 0.06^{*}$ & $4.02 \pm 0.09^{*}$ & $4.65 \pm 0.15^{*}$ & $5.90 \pm 0.11$ \\
\hline $20 \mathrm{mg} / \mathrm{kg} 5-\mathrm{FU}$ & $2.05 \pm 0.03^{*}$ & $2.27 \pm 0.04^{*}$ & $2.45 \pm 0.03^{*}$ & $2.69 \pm 0.02$ & $2.96 \pm 0.03$ \\
\hline
\end{tabular}

Values are represented as mean \pm SEM. ${ }^{*}<<0.05$ when compared to Control (D10). Data were analyzed by one-way ANOVA followed by Dunnett's test. 


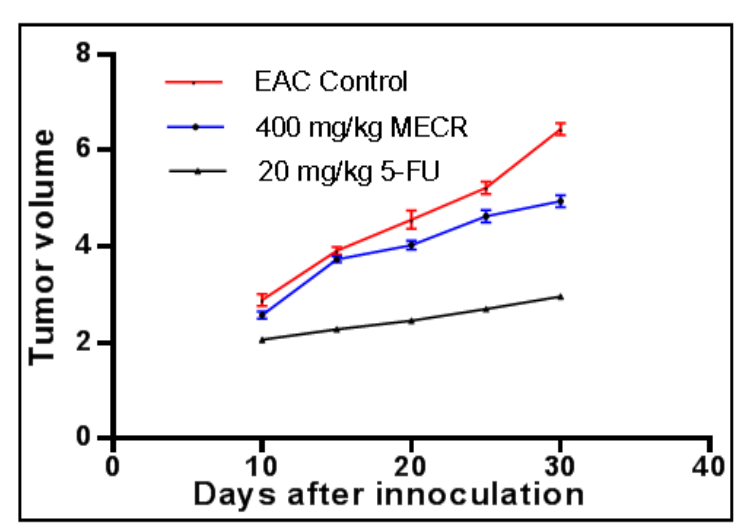

Fig. 4: Time related change in solid tumor volume, data are plotted as tumor volume vs. time (D) \pm SEM

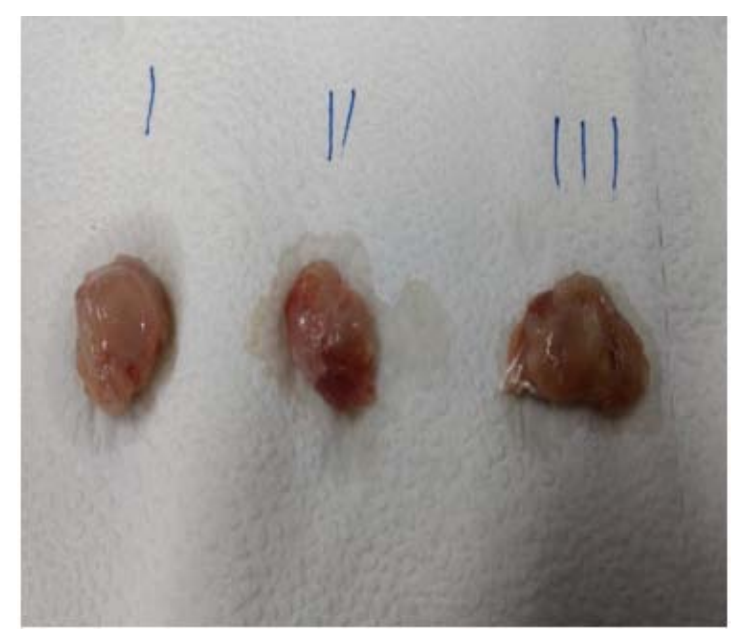

Fig. 5: Representative photographs of tumor size where (iii) means EAC Control, (ii) means $5-F U 20 \mathrm{mg} / \mathrm{kg}$ and (i) means MECR400 mg/kg

\section{DISCUSSION}

In present inspection, EAC cell line was used to inspect the anticancer features of MECR. The reason behind the choice of EAC cell (cell line origin: murine mammary) is for its high transplantable capability, $100 \%$ malignancy, rapid proliferation and hostile nature. Ascitic fluid works as a direct nutritional source for augmentation of tumor cells [16]. MECR treatment materially reduced tumor volume probably by lowering the ascitic nutritional fluid volume. Further, the packed cell volume and the number of viable cell were significantly lower in the mice treated with MECR when compared to the EAC control group. These results could imply either a direct cytotoxic impact of MECR on tumor cells or an indirect local effect, involving macrophage activation and vascular permeability inhibition [17]. Prolongation of life span of the treated animals is a well founded benchmark for judging the value of any anticancer entity [18]. The increase of life span of tumor bearing mice by MECR treatment is a positive result and supports the antitumor effect of MECR. Myelosuppression and anemia are crucial complications of cancer chemotherapy [19]. The anemia occurring is mainly due to reduction in erythrocyte or hemoglobin percentage because of iron shortage or hemolytic or myelopathic state [20]. Treatment with MECR brought back the hemoglobin content, RBC and leucocytes cell count near to normal values. This indicates that MECR possesses minimum toxic effect on hematological system and favors its potential as an anticancer candidate.

Enzymes in serum have been studied for many years as possible early indicators of neoplasia and as aids in following the progression and regression of disease [21]. Hepatotoxicity may occur due to cytotoxic agent itself or due to its toxic metabolites. From the experiment it was found that EAC control group exhibited increased levels of liver specific enzymes such as SGOT, SGPT and ALP while the levels of total protein were decreased due to hepatocellular damages. The MECR treated group showed restoration of these biochemical parameters to more or less normal levels.

The lack of balance between the reactive oxygen metabolites and the antioxidant defence systems leads to "oxidative stress" which deregulates various cellular functions causing pathological conditions [22]. Reactive oxygen species (ROS) formed in cancer tissues result in lipid peroxidation and subsequent increase in MDA and other TBARS levels. MDA, the end product of lipid peroxidation, a biomarker of oxidative stress, was reported to be higher in cancer tissues than in the non-diseased organ [23]. The present study showed that TBARS level measured as MDA in the EAC bearing liver tissues were higher than those in normal treated liver tissues. Treatment with MECR inhibited hepatic lipid peroxidation as revealed by curtailment of MDA levels towards normal levels. This pointed out the reduction in free radical generation by MECR in tumor bearing mice.

Glutathione (mother of all antioxidants), a dynamic inhibitor of neopalstic system, plays a key function as an endogenous antioxidant process which is found abundantly in liver and works as in defensive way [24]. Reduced glutathione known as body's own master antioxidant was found to be minimized in cancer bearing mice which might be due to its exploitation by the presence of superabundant free radicals. MECR treatment was observed to escalate the non enzymatic GSH content in liver as compared to EAC control group. Enzymatic antioxidant (SOD) is ubiquitous in all oxygen-metabolizing cells possessing free radical scavenging system to provide a barricade against superoxide (by product of oxygen metabolism) and stable molecule hydrogen peroxide (highly accused damaging species). Inhibition of SOD activities as a result of tumor growth was also reported and similar findings were obtained in the present investigation with EAC-bearing mice. Treatment with MECR significantly increased the SOD level indicating an affirmation of antioxidant and free radical scavenging activity of the extract. Effect on solid tumor treatment by MECR reveals a prominent hope by decreasing tumor volume and plays a direct role in killing tumor cells and enhances the curative effect of tumor chemotherapy. It shows that extract is cytotoxic.

\section{CONCLUSION}

Present investigation provides a promising exploration on anticancer activity of MECR probably because of its direct cytotoxic effect followed by its antioxidant properties. Also $400 \mathrm{mg} / \mathrm{kg}$ MECR showed better response compared to $200 \mathrm{mg} / \mathrm{kg}$ MEQL suggesting a possible dose dependent influence of the extract on cancer. Initial phytochemical screening unveiled the existence of flavonoid, alkaloids, saponin, and carbohydrate in MECR. Flavonoids possess antimutagenic and antimalignant effect through signal transduction in cell proliferation and angiogenesis. Alkaloids, better known for healing power of some serious illness including cancer, might be responsible alone or both (including flavonoids) combined for anticancer and cytotoxic activities of MECR. Further research is ongoing in our laboratory to find out the bioactive molecule(s) for the anticancer activity of the extract.

\section{ACKNOWLEDGEMENT}

Department of Pharmaceutical Technology, Jadavpur University, Kolkata, India are gratefully acknowledged.

\section{AUTHOR CONTRIBUTION}

Subeer Roy: Done the Experiment protocol, Data collection and analysis, drafting article, writing manuscript

Diksha Kumari: Done the Experiment protocol, Data collection and analysis, critical revision of the article

Mainak Chakraborty: Done the Experiment protocol, Data analysis.

Dr. Pallab Kanti Haldar: Design of the work, data analysis, critical revision of the article, final approval of the article. 


\section{CONFLICT OF INTERESTS}

Declared none

\section{REFERENCES}

1. Hanahan D, Weinberg RA. The hallmarks of cancer. Cell 2000;100:57-70.

2. Srivasthava JK, Gupta S. Tocotrienol-rich fraction of palm oil induces cell cycle arrest and apoptosis selectively in human prostate cancer cells. Biochem Biophys Res Commun 2006;346:447-53.

3. Saha P, Mazumder UK, Haldar PK, Naskar S, Kundu S, Bala A, Kar B. Anticancer activity of methanol extract of Cucurbita maxima against Ehrlich ascites carcinoma. Int J Res Pharm Sci 2011;2:52-9.

4. Gordaliza M. Natural products as leads to anticancer drugs. Clin Transl Oncol 2007;9:767-76.

5. Basumatary SK, Ahmed M, Deka SP. Some medicinal plant leaves used by Boro (tribal) people of Goalpara district, Assam. Nat Prod Res 2004;3:88-90.

6. Patari P, Uddin MJ. Documentation and consensus of agreements on Indigenous knowledge of medicinal plants used by the Mog, Reang, Uchai of South Tripura: A preliminary report. J Med Plants Stud 2016;4:122-37.

7. Gupta A and Chaphalkas SR. Immunosuppressive activity of crude saponins from the leaves of Caloptropis gigantean, Calamus rotang and Artocarpus integrifolia. IJPSR 2015;5:1-5.

8. Ripa FA, Dash PR and Faruk MO. CNS depressant, analgesic and anti inflammatory activities of methanolic seed extract of Calamus rotang fruits in rat. J Pharmacogn Phytochem 2015;3:121-25.

9. Chakraborty M, Karmakar I, Haldar S, Nepal A, Haldar PK. Anticancer and antioxidant activity of methanol extract og Hippophae salicifolia in EAC induced swiss albino mice. IJPPS 2015; 7:180-84

10. Bala A, Kar B, Haldar PK, Mazumder UK, Bera S. Evaluation of anticancer activity of Cleome gynandra on Ehrlich's ascites carcinoma treated mice. J Ethnopharmacol 2010;129:131-34.

11. Sur, P., Ganguly, D. K. Tea plant roots extract (TRE) as an antineoplastic agent.

12. Planta Med 1994. 60:106-9.
13. Ohkawa, H., Oishi, N. and Yagi, K. 'Assay for lipid peroxides in animal tissue by thiobarbituric acid reaction'. Anal Biochem 1979;95:351-58.

14. Kakkar, P., Das, B., Vishwanathan, P. N. A modified spectrophotometric assay of superoxide dismutase. Indian J Biochem Biophys 1984;21:130-32.

15. Ellman, G. L. 'Tissue sulphydryl groups'. Arch Biochem Biophys 1959;82:70-72.

16. Kumar RJ, Rajkapoor B, Perumal P, Dhanasekaran T, Jose MA, Jothimanivannan C. Antitumor Activity of Prosopis glandulosa Torr. on Ehrlich AscitesCarcinoma (EAC) Tumor Bearing Mice. IJPR 2011. 10:505-10.

17. Shimizu M, Azuma C, Taniguchi T, Murayama T. Expression of cytosolic phospholipase A2 $\alpha$ in murine C12 cells, a variant of L929 cells, induces arachidonic acid release in response to phorbol myristate acetate and Ca2+ionophores, but not to tumor necrosis factor- $\alpha$. J Pharmacol Sci 2004;96:324-32.

18. Bala A, Kar B, Haldar PK, Majumder UK, Bera S. Evaluation of anticancer activity of Cleome gynandra on Ehrlich's ascites carcinoma treated mice. J Ethnopharmacol 2010;129;131-34.

19. Pal P, Prasad AK, Chakraborty M, Haldar S, Majumder P, Haldar PK. Evaluation of anti cancer potential of methanol extract of curcuma zedoaria. Asian J Pharm Clin Res 2015;8:271-75.

20. Price VE and Greenfield RE. Anemia in cancer, in: Greenstein, J. P., Haddow, A., (eds.) 20 Advances in cancer research. New York: Academic Press 1958;5:199-200.

21. Fenninger, LD., and Mider, G. B. in 'Advances in cancer research'. Grenstein, J. P., and Haddow, A., (eds.) vol II. New York: Academic Press 1954 p.244.

22. Kathiriya K, Das EP, Kumar KB. Mathai Evaluation of antitumor and antioxidant activity of Oxalis corniculata Linn. against Ehrlich Ascites Carcinoma on mice. Iranian Journal CancerPreview 2010;3:157-65.

23. Bandyopadhyay, U., Das, D. and Banerjee, R. K. 'Reactive oxygen species: Oxidative damage and pathogenesis'. Curr. Sci 1999;77:658.

24. Yagi K. Lipid peroxides and human diseases. Chem Physiol Lip 1991;45:337-51.

25. Sinclair, A. J., Barnett, A. H. and Lunie, J. 'Free radical and autooxidant systems in health and disease. Br J Hosp Med 1990:43:334-44. 